\title{
Simulation of isothermal kinetics of martensitic transformation in the $\mathrm{Ti}_{40.7} \mathrm{Hf}_{9.5} \mathrm{Ni}_{44.8} \mathrm{Cu}_{5}$ alloy
}

\author{
E. S. Demidova ${ }^{\dagger}$, S. P. Belyaev, N. N. Resnina \\ †lena-demi@yandex.ru
}

Saint Petersburg State University, 7/9 Universitetskaya Quay, St. Petersburg, 199034, Russia

\begin{abstract}
The realization of forward martensitic transformation under isothermal conditions in NiTi-based alloys has been well studied experimentally, along with the kinetics of this process. However, existing models do not allow the isothermal martensite volume fraction $\Phi_{M}$ to be estimated, hence the influence of holding temperature or time on the $\Phi_{M}$ value could not be calculated. The Johnson-Mehl-Avrami-Kolmogorov (JMAK) theory is normally used to describe isothermal kinetics, but it has not been applied for martensite transformation, which occurs in shape-memory alloys during holding at a constant temperature. Thus, the aim of the present study is to adapt the JMAK theory and use to estimate $\Phi_{M}$ variation with time during holding of $\mathrm{Ti}_{40.7} \mathrm{Hf}_{9.5} \mathrm{Ni}_{44.8} \mathrm{Cu}_{5}$ alloy at different temperatures. The JMAK equation allows the variation of the isothermal martensite volume fraction with time during holding at constant temperatures to be approximated. It was applied to estimate experimental $\Phi_{M}(t)$ curves in $\mathrm{Ti}_{40.7} \mathrm{Hf}_{9.5} \mathrm{Ni}_{44.8} \mathrm{Cu}_{5}$ alloy and a good approximation was established. The dependencies of JMAK-like equation parameters on the holding temperature were also found and approximated. Thus, the expression for the dependence of the isothermal martensite volume fraction on holding temperature and time was found and calculation of the $\Phi_{M}(t)$ curves was carried out. The simulated and experimental data for the $\mathrm{Ti}_{40.7} \mathrm{Hf}_{9.5} \mathrm{Ni}_{44.8} \mathrm{Cu}_{5}$ shape memory alloy were shown to be in good agreement.
\end{abstract}

Keywords: shape memory alloys, martensitic transformation, isothermal kinetics, Avrami theory.

УДК: 536.65

\section{Расчет изотермической кинетики мартенситного перехода в сплаве $\mathrm{Ti}_{40.7} \mathrm{Hf}_{9.5} \mathrm{Ni}_{44.8} \mathrm{Cu}_{5}$

\author{
Демидова Е. С. ${ }^{\dagger}$, Беляев С. П., Реснина Н.Н.
}

Санкт-Петербургский Государственный Университет, Университетская наб., 7/9, С.-Петербург, 199034, Россия

Реализация прямого мартенситного превращения в изотермических условиях в сплавах на основе NiTi хорошо изучена экспериментально вместе с кинетикой этого процесса. Однако существующие теоретические модели не позволяют оценить объемную долю изотермически образованной мартенситной фазы $\Phi_{м}$, следовательно, влияние температуры или длительности выдержки на величину $\Phi_{M}$ не может быть рассчитано. Теорию ДжонсонаМела-Аврами-Колмогорова (ЈМАК теорию) обычно используют для описания изотермической кинетики, однако она не была применена для моделирования образования мартенситной фазы во время выдержки при постоянной температуре в сплавах с памятью формы. В связи с этим, целью настоящего исследования является адаптация JМАК теории и ее применение для расчета изменения $\Phi_{M}$ во времени в течение выдержки сплава $\mathrm{Ti}_{407} \mathrm{Hf}_{95} \mathrm{Ni}_{448} \mathrm{Cu}_{5}$ при различных температурах. Показано, что уравнение, типа ЈМАК, позволяет аппроксимировать изменение объемной доли изотермически образованного мартенсита со временем в условиях выдержки при постоянной температуре. Это уравнение было использовано для аппроксимации экспериментальных данных $\Phi_{M}(t)$, полученных для сплава $\mathrm{Ti}_{40.7} \mathrm{Hf}_{9.5} \mathrm{Ni}_{44.8} \mathrm{Cu}_{5}$, и установлено хорошее приближение. Найдены и аппроксимированы зависимости параметров уравнения типа ЈМАК от температуры выдержки. Таким образом, получена зависимость объемной доли изотермически образованного мартенсита от температуры и длительности выдержки, и проведен расчет кривых $\Phi_{M}(t)$. Показано, что рассчитанные и экспериментальные зависимости, полученные для сплава с памятью формы $\mathrm{Ti}_{40.7} \mathrm{Hf}_{9.5} \mathrm{Ni}_{44.8} \mathrm{Cu}_{5}$, хорошо согласуются друг с другом.

Ключевые слова: сплавы с памятью формы, мартенситные превращения, изотермическая кинетика, теория Аврами. 
In recent years, it has been found that in some NiTi-based alloys, the thermoelastic martensitic transformation can occur during holding at a constant temperature that is higher than the starting temperature of the forward transition $M_{s}[1-7]$ or within the temperature range of the forward transformation [1,5-10]. This phenomenon has been well studied experimentally and the kinetics of this process is described in [4-6]. It has been shown that the volume fraction of isothermally transformed martensite phase increases with time up to saturation, the value of which depends on the holding temperature $T^{\star}$ and the alloy composition.

Existing models describing the isothermal kinetics of the thermoelastic martensitic transformation in NiTi-based alloys are based on different explanations of this phenomenon. In $[8-11]$, the isothermal martensite transformation is considered to be a thermoactivated process that may occur during holding at temperatures within the temperature range of the forward transition. This model allows the isothermal martensite transformation rate to be estimated using the logarithmic dependence of resistance on time. In $[3,12]$ it is assumed that the isothermal transformation from the austenite to the martensite state may take place only when a certain critical energy is acquired due to some thermoactivated process. This model estimates the probability of the isothermal martensite transformation and calculates the incubation time needed for this phenomenon. It is worth noting that the existing models do not allow the isothermal martensite volume fraction $\Phi_{M}$ to be estimated, hence the influence of holding temperature or time on the $\Phi_{M}$ value could not be simulated.

The kinetics of new phase formation during isothermal transformations that take place in metals and alloys could be described by the Johnson-Mehl-Avrami-Kolmogorov (JMAK) theory $[13,14]$. According to this theory, the variation of the volume fraction of the new phase $\Phi$ with time is estimated as:

$$
\Phi=1-e^{-k t^{n}}
$$

where $k$ is a temperature-dependent parameter, $t$ is the holding duration, and $n$ is a constant in the range 0.5-4 that depends on the geometry of the grains of the new phase. However, no attempts at simulation of $\Phi_{M}(t)$ curves according to the JMAK model have been made for NiTibased alloys. Thus, the aim of the present study is to adapt and use the JMAK theory for estimation of $\Phi_{M}$ variation with time during holding of $\mathrm{Ti}_{40.7} \mathrm{Hf}_{9.5} \mathrm{Ni}_{44.8} \mathrm{Cu}_{5}$ alloy at different temperatures. $\mathrm{Ti}_{40.7} \mathrm{Hf}_{9.5} \mathrm{Ni}_{44.8} \mathrm{Cu}_{5}$ alloy was chosen due to it underwent the martensitic transformation during isothermal holding and a large amount of experimental data was available on the isothermal kinetics of thermoelastic martensitic transformations for this alloy $[4,5]$. In [4] it is shown that the fully crystalline $\mathrm{Ti}_{40.7} \mathrm{Hf}_{9.5} \mathrm{Ni}_{44.8} \mathrm{Cu}_{5}$ alloy with the grain size of $700 \mathrm{~nm}$ (details of crystallization are described in [4]) undergoes $\mathrm{B} 2 \leftrightarrow \mathrm{B} 19^{\prime}$ martensitic transformations at temperatures: $M_{s}=266 \mathrm{~K}, M_{f}=260 \mathrm{~K}$, $A_{s}=302 \mathrm{~K}$ and $A_{f}=325 \mathrm{~K}[4]$.

According to the data obtained in [4-6] during isothermal holding, non-complete transformation to the martensite phase occurs. Therefore, to simulate the isothermal kinetics of the thermoelastic martensitic transition in NiTi-based alloys, the JMAK equation is transformed to

$$
\Phi_{M}=f\left(1-e^{-k t^{n}}\right)
$$

where the $f$ is temperature dependent value which is equal to $100 \%$ if the complete isothermal transformation takes place, otherwise this value is less than $100 \%$.

To simulate the isothermal kinetics of the martensitic transformation via the JMAK-equation, the experimental $\Phi_{M}(t)$ curves obtained during holding at different temperatures were approximated by Eq. (2) using OriginPro software (Fig. 1). One may note, that the approximated curves are in good agreement with experimental data however, it should be mentioned that for curves obtained at different holding temperatures different parameters of the JMAK-equation $(k, n, f)$ were used. Fig. 2 shows the variation of $k$ and $f$ parameters with $\Delta T$ value (difference between the holding temperature $T^{\star}$ and $M_{s}$ ) and it is seen, that these dependencies are non-monotonic. At $\Delta T<0$ an increase in holding temperature leads to an increase in $k$ value otherwise $k$ decreases when $\Delta T>0$ (Fig. $2 \mathrm{a}$ ). The $f$ value increases from 20 to $80 \%$ with an increase in $\Delta T$ from -4 to $0 \mathrm{~K}$, it remains constant when $\Delta T$ is in the range from 0 to $2 \mathrm{~K}$, and $f$ value decreases when $\Delta T>2 \mathrm{~K}$ (Fig. $2 \mathrm{~b}$ ). The parameter $n$ is found to be 0.5 at $\Delta T<0$, otherwise the $n$ value is equal to 0.9 . Such dependencies of $k, n, f$ parameters on $\Delta T$ is in a good agreement to $[6,7]$ where it is shown that kinetics of the isothermal martensite transformation in NiTi-based alloys is different at $\Delta T<0\left(T^{\star}<M_{s}\right)$ or $\Delta T>0\left(T^{\star}>M_{s}\right)$. Thus, in the present work, the dependencies of $k, n, f$ parameters on $\Delta T$ were approximated separately for the cases of $\Delta T>0$ and $\Delta T<0$.

In the JMAK theory, $k$ is a 'frequency' factor that characterizes the rate of the new phase formation. In [15] it is shown that this rate is influenced by two factors: the driving force of the phase transformation $\Delta G$ and atom mobility $v$. It is obvious that the rate of formation of the new phase should also depend on the volume fraction of the austenite phase $\Phi_{0}^{A}$. Therefore, $k(T)$ may be given as:

$$
k \sim \Delta G \cdot v \cdot \Phi_{0}^{A},
$$

where $\Delta G$ corresponds to the driving force of the forward martensitic transformation, $v$ reflects atom mobility and

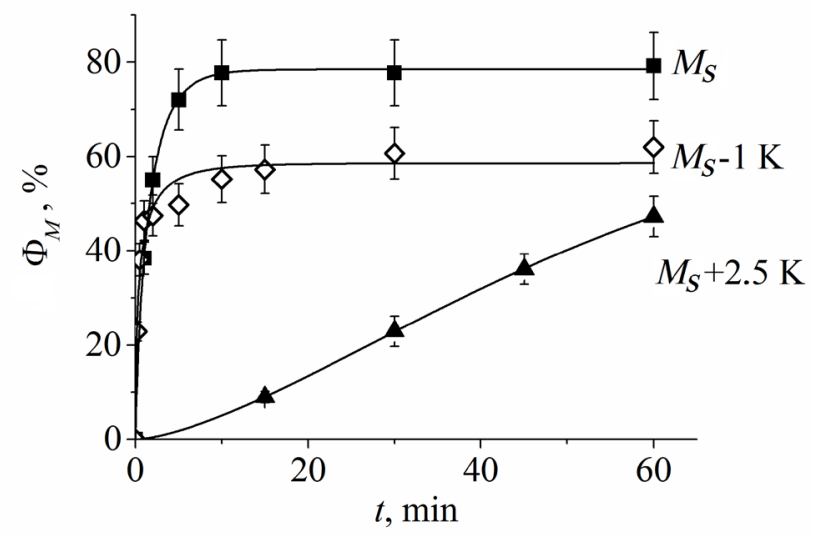

Fig. 1. Dependencies of isothermal martensite volume fraction $\Phi_{M}$ on holding duration: experimental data (points) and approximated curves (lines). 


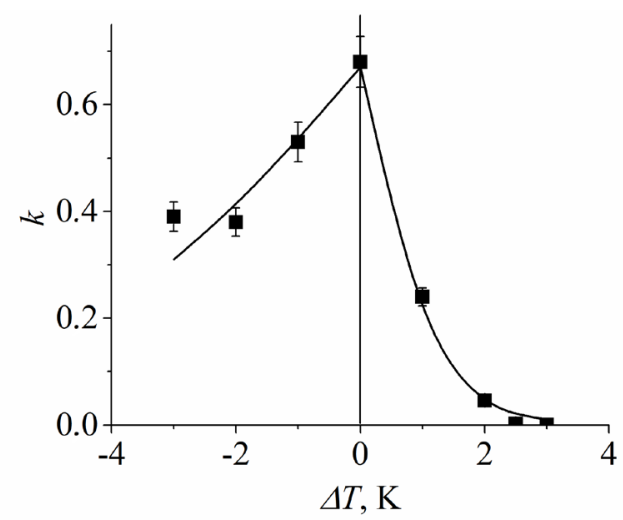

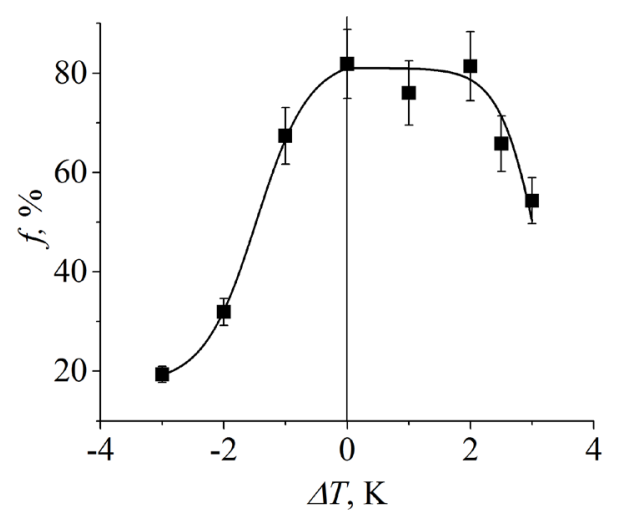

b

Fig. 2. Dependencies of JMAK-like equation parameters $k(\mathrm{a})$ and $f(\mathrm{~b})$ on $\Delta T$ (difference between holding temperature $T^{\star}$ and $M_{s}$ ).

$\Phi_{0}^{A}$ is the volume fraction of the austenite phase in the alloy before holding that may transform to the martensite state. It can be supposed that driving force increases exponentially with a decrease in temperature:

$$
\Delta G \sim e^{-\beta \cdot\left(T^{*}-T_{0}\right)},
$$

whereb $\beta$ is a constant, $T_{0}$ is the temperature of the thermodynamic equilibrium and $T^{*}$ is the holding temperature. The value of $T_{0}$, equal to $\left(M_{s}+A_{f}\right) / 2=316 \mathrm{~K}$, was found by analysing the martensitic transformation temperatures that were measured in annealed $\mathrm{Ti}_{40.7} \mathrm{Hf}_{9.5} \mathrm{Ni}_{44.8} \mathrm{Cu}_{5}$ alloy [16]. Atom mobility $v$ is proportional to the Boltzmann factor:

$$
v \sim e^{-\frac{U^{*}}{k_{B} T^{*}}},
$$

where $U^{\star}$ is the activation energy of vacancy migration, which is equal to $0.7 \mathrm{eV}$ for the NiTi-based alloys [17], and $k_{B}$ is the Boltzmann constant.

The dependence of $\Phi_{0}^{A}(T)$ was estimated as the difference $1-\Phi$, where $\Phi$ is the volume fraction of the martensite phase in the alloy before holding. To determine the $\Phi$ value, integration of the calorimetric curve obtained on cooling of the studied sample was carried out (Fig. 3). The $\Phi(T)$ curve is

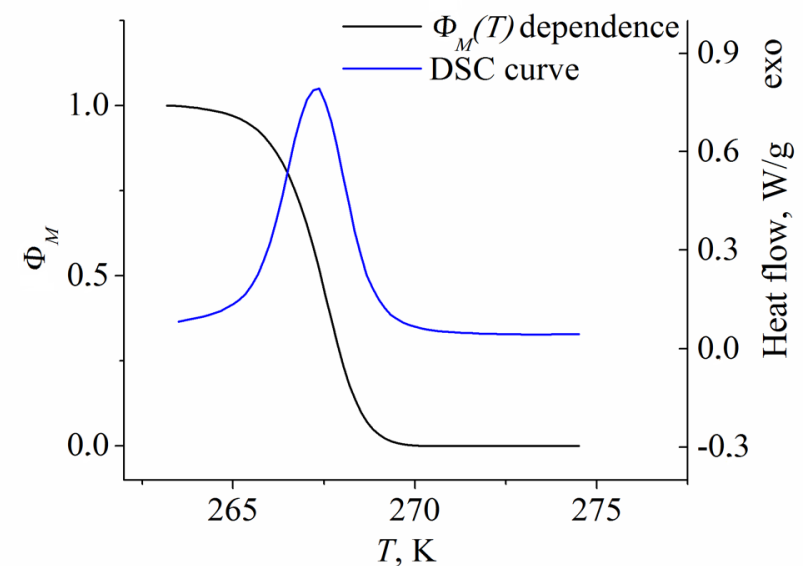

Fig. 3. (Color online) Dependence of the martensite volume fraction on temperature (black line) and the calorimetric curve (blue line) obtained during cooling of the $\mathrm{Ti}_{40.7} \mathrm{Hf}_{9.5} \mathrm{Ni}_{44.8} \mathrm{Cu}_{5}$ alloy in the temperature range of the forward transformation. approximated by a sigmoidal function using OriginPro and is found to be:

$$
\Phi=\frac{1}{1+e^{\frac{T^{*}-267.5}{0.6}}} .
$$

At temperatures higher than $M_{s}$ the alloy is in the austenite state, hence the $\Phi$ value is zero.

Taking into account the equations described above, the parameter $k$ is expressed as

$$
\begin{gathered}
k=a \cdot \Phi_{0}^{A} \cdot e^{-\frac{U^{*}}{k_{B} T^{*}}} \cdot e^{-\beta \cdot\left(T^{*}-T_{0}\right),} \\
\left\{\begin{array}{l}
\Phi_{0}^{A}=1, \\
\Phi_{0}^{A}=1-\frac{1}{1+e^{\frac{T^{*}-267.5}{0.6}}}, T^{*} \leq M_{S}
\end{array}\right.
\end{gathered}
$$

where $a$ and $\beta$ are constants. Eq. (7) was used to approximate the $k(\Delta T)$ curve given in Fig. $2 \mathrm{a}$. It was found that $\beta=1.5$ and that $a=3.17 \times 10^{-20} \mathrm{~s}^{-1}$ for $T^{*}>M_{s}$ or $4.3 \times 10^{-19} \mathrm{~s}^{-1}$ for $T^{\star} \leq M_{s}$.

Parameter $f$ in the JMAK-like equation (Eq. (2)) is associated with the maximum volume fraction of the martensite phase, which may appear during isothermal holding. The $f(\Delta T)$ dependence was described using sigmoidal function

$$
f=A+\frac{B}{1+e^{\frac{\Delta T+C}{D}},}
$$

where $\Delta T$ is the difference between $M_{s}$ and holding temperature $T^{\star}$ and $A, B, C$ and $D$ are parameters determined using an approximation of the $f(\Delta T)$ curve presented in Fig. 2 b. These parameters are: $A=0, B=81, C=-3.16$, $D=0.33$ when the holding temperature is less than $M_{s}$ $(\Delta T>0)$; and $A=83, B=-65.5, C=-1.5, D=0.43$ when the holding temperature is larger than $M_{s}(\Delta T<0)$.

Using Eqs. (2), (7) and (8), the dependencies of the isothermal martensite volume fraction on the holding time at different temperatures $T^{\star}$ are calculated and shown in Fig. 4 , together with the experimental data found for $M_{s}+1 \mathrm{~K}$ and $M_{s}-3 \mathrm{~K}$. It is seen, that a good agreement between the calculated curves and experimental data is observed. 


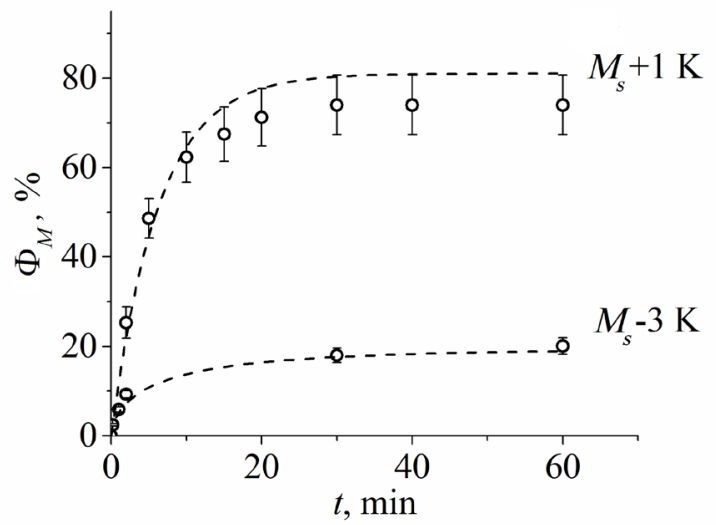

Fig. 4. Experimental (points) and simulated (lines) dependencies of isothermal martensite volume fraction $\Phi_{M}$ on holding duration found for the $\mathrm{Ti}_{40.7} \mathrm{Hf}_{9.5} \mathrm{Ni}_{44.8} \mathrm{Cu}_{5}$ alloy.

Thus, the following conclusions could be made:

1. The equation based on the JMAK theory allows the variation of the isothermal martensite volume fraction with time during holding at constant temperatures to be approximated.

2. The dependencies of the JMAK-like equation parameters $f, k$ and $n$ on the holding temperature $T^{\star}$ are found.

3. Calculation of the $\Phi_{M}(t)$ curves is carried out using the modified JMAK equation and good agreement with experimental data is found for the $\mathrm{Ti}_{40.7} \mathrm{Hf}_{9.5} \mathrm{Ni}_{44.8} \mathrm{Cu}_{5}$ shape memory alloy.

Acknowledgements. The work was supported by Russian Foundation for Basic Research (grant number 18-38-00362mol_a).

\section{References}

1. T. Fukuda, S. Yoshida, T. Kakeshita. Scripta Mater. 68, 984 (2013). Crossref

2. T. Fukuda, M. Todai, T. Kakeshita. Scripta Mater. 69, 239 (2013). Crossref
3. T. Fukuda, T. Kawamura, T. Kakeshita. J Alloy Compd. 683, 481 (2016). Crossref

4. N. Resnina, S. Belyaev, A. Shelyakov. Scripta Mater. 112, 106 (2016). Crossref

5. E. Demidova, S. Belyaev, N. Resnina, A. Shelyakov. J Therm Anal Calorim. 139, 2965 (2020). Crossref

6. N. Resnina, S. Belyaev, E. Demidova, A. Ivanov, V. Andreev. Mater Lett. 228, 348 (2018). Crossref

7. Y. Ji, D. Wang, X. Ding, K. Otsuka, X. Ren. Phys Rev Lett. 114, 055701 (2015). Crossref

8. S. Kustov, D. Salas, E. Cesari, R. Santamarta, J. Van Humbeeck. Acta Mater. 60, 2578 (2012). Crossref

9. D. Salas, E. Cesari, J. VanHumbeeck, S. Kustov. Scripta Mater. 74, 64 (2014). Crossref

10. S. Kustov, D. Salas, R. Santamarta, E. Cesari, J. Van Humbeeck. Scripta Mater. 63, 1240 (2010). Crossref

11. S. D. Prokoshkin, I. Yu. Khmelevskaya, S. V. Dobatkin, I. B. Trubitsyna, E.V. Tatyanin, V.V. Stolyarov, E. A. Prokofiev. Acta Mater. 53, 2703 (2005). Crossref

12. T. Kakeshita, T. Fukuda, T. Saburi. Scripta Mater. 34, 147 (1996). Crossref

13. J.W. Christian. The Theory of Transformations in Metals and Alloys. Oxford, Pergamon Press (1965) $1200 \mathrm{p}$.

14. M. Avrami. J Chem Phys. 8, 212 (1940). Crossref

15. MSE 2090: Introduction to Materials Science Chapter 10, Phase Transformations. URL: http://people.virginia. edu/ lz2n/mse209/Chapter10.pdf

16. S. Belyaev, N. Resnina, A. Shelyakov. Smart Mater Struct. 24, 045013 (2015). Crossref

17. A. I. Lotkov, A. A. Baturin. Pozitronnaya spectroscopiya B2-soedineniy titana. Tomsk, Izdatelstvo nauchno-technicheskoy literatury (2004) 231 p. (in Russian) [А.И. Лотков, А.А. Батурин. Позитронная спектроскопия В2-соединений титана. Томск, Издательство научно-технической литературы (2004) 231 c.] 